\title{
Evaluasi Program Pelatihan Peningkatkan Kompetensi Pendidik Paud
}

\author{
Fatmawati Ngadi ${ }^{1}$, Zulkarnain Anu ${ }^{2}$ \\ Dinas Pendidikan dan Kebudayaan Kabupaten Bolaang Mongondow Utara, Universitas Negeri Gorontalo \\ fatmangadi@gmail.com, infozulkarnain@gmail.com
}

Received: 10 Desember 2020; Revised: 27 Desember 2020; Accepted: 28 Desember 2020

\begin{abstract}
This study aims to determine: (1) evaluation of the component evaluation of the training program to improve the competence of early childhood educators at the North Bolaang Mongondow Regency Office, (2) to evaluate the input component of the evaluation of the training program to improve the competence of early childhood educators in the North Bolaang Mongondow Regency Service, (3) component of the evaluation process of the PAUD educator competency improvement training program in North Bolaang Mongondow Regency, (4) evaluation of the product component (result) of the evaluation of the PAUD educator competency improvement training program in Bolaang Mongodow Utara Regency. The method used in this research is descriptive method with the CIPP evaluation model covering aspects of the context, input, process, and product training program to increase the competence of early childhood educators. Data were collected through observation, interviews, documentation. The findings of the research results are first, the results of the evaluation of the components of the training program for the improvement of the competence of early childhood educators in Bolaang Mongondow Utara Regency are in the good category. Second, the results of the evaluation of the input component of the PAUD teacher competency improvement training program in Bolaang Mongondow Utara Regency are in the very good category. Third, the results of the evaluation of the components of the training program process for improving the competence of early childhood educators in Bolaang Mongodow Utara Regency are in the very good category. Fourth, the results of the evaluation of the input components for the training program to improve the competence of early childhood educators in Bolaang Mongondow Utara Regency are in the sufficient category.
\end{abstract}

Keywords: Evaluation of training programs, the competence of early childhood education.

Penelitian ini bertujuan untuk mengetahui: (1) evaluasi komponen contexct evaluasi program pelatihan peningkatan kompetensi pendidik PAUD di Dinas Kabupaten Bolaang Mongondow Utara, (2) evaluasi komponen input evaluasi program pelatihan peningkatan kompetensi pendidik PAUD di Dinas Kabupaten Bolaang Mongondow Utara, (3) evaluasi komponen proses evaluasi program pelatihan peningkatan kompetensi pendidik PAUD di Kabupaten Bolaang Mongondow Utara, (4) evaluasi komponen product (hasil) evaluasi program pelatihan peningkatan kompetensi pendidik PAUD di Kabupaten Bolaang Mongodow Utara. Metode yang digunakan dalam penelitian ini adalah metode deskriptif dengan model evaluasi CIPP meliputi aspek context, input, proses, dan produk program pelatihan peningkatan kompetensi pendidik PAUD. Sumber data dalam penelitian ini adalah sumber data primer dan data sekunder. Temuan hasil penelitian adalah pertama, hasil evaluasi terhadap komponen contexct program pelatihan peningkatan kompetensi pendidik PAUD di Kabupaten Bolaang Mongondow Utara berada pada kategori baik. Kedua, hasil evaluasi terhadap komponen input program pelatihan peningkatan kompetensi pendidik PAUD di Kabupaten Bolaang Mongondow Utara berada pada kategori sangat baik. Ketiga, hasil evaluasi terhadap komponen proses program pelatihan peningkatan kompetensi pendidik PAUD di Kabupaten Bolaang Mongodow Utara berada pada kategori sangat baik. Keempat, hasil evaluasi terhadap komponen masukan program pelatihan peningkatan kompetensi pendidik PAUD di Kabupaten Bolaang Mongondow Utara berada pada kategori cukup.

Kata kunci: Evaluasi program pelatihan, kompetensi pendidik PAUD. 


\section{PENDAHULUAN}

Salah satu strategi peningkatan mutu pendidik PAUD yang telah diberlakukan selama ini melalui pengembangan gugus. Upaya peningkatan mutu pendidik seperti yang dipersyaratkan dalam Undang-Undang Nomor 14 Tahun 2005 tentang Dosen dan Pendidik, menjadikan gugus sebagai pintu masuk pertama (starting gate) yang strategis. Salah satu program pengembangan gugus adalah pendidikan dan pelatihan. Pelatihan merupakan salah satu cara yang efektif untuk meningkatkan hasil kerja seorang pendidik, pengetahuan, ketrampilan serta sikap tertentu. Untuk dapat menjadi pendidik profesional antara lain dengan jalan melaksanakan micro teaching. Latihan micro teaching ini disebut juga dengan latihan in service, yaitu latihan bagi pendidik. Kegunaan latihan in service ini adalah: (1) Untuk meningkatkan kemampuan pendidik, upaya menemukan kelemaham-kelemahan sendiri dan berusaha memperbaikinya. (2) Untuk meningkatkan kemampuan fasilitator dalam upaya membantu meningkatkan kemampuan pendidik, (3) Untuk percobaan melaksanakan teknik-teknik baru, sebelum teknik itu dilaksanakan dalam kelas sebenarnya

Sesuai dengan data yang peneliti peroleh dari Dinas Pendidikan dan Kebudayaan Kabupaten Bolaang Mongondow Utara, sebagian besar pendidik PAUD tidak memiliki kualifikasi pendidikan dibidang kependidikan bahkan paling banyak berpendidikan setingkat SMA. Data yang diperoleh tentang pendidik PAUD Berdasarkan Pendidikan di Kabupaten Bolaang Mongondow Utara untuk tahun 2016 yaitu pendidik PAUD lebih banyak yang berpendidikan SMA dengan jumlah 440 orang atau $85,3 \%$. Selanjutnya pada pendidik PAUD lulusan sarjana berjumlah 50 orang atau 9,7\%. Dari jumlah tersebut 35 orang sesuai latar belakang pendidikan PAUD dan 15 orang tidak sesuai latar belakang pendidikan PAUD, sedangkan yang berpendidikan Diploma berjumlah 26 orang atau 5\%, di antaranya 20 orang sesuai latar belakang pendidikan PAUD dan 6 orang tidak sesuai latar belakang pendidikan PAUD. Pendidik diberi peluang dan kesempatan untuk mengembangkan segenap potensinya melalui pelatihan. Melalui pelatihan diharapkan kinerja pendidik akan meningkat dengan semakin 
baiknya pelaksanaan kegiatan belajar mengajar, termasuk juga kemampuan memanfaatkan teknologi informasi untuk kepentingan pembelajaran.

Menurut Hamalik (2007: 10) bahwa pelatihan adalah suatu proses yang meliputi serangkaian tindak (upaya) yang dilaksanakan dengan sengaja dalam bentuk pemberian bantuan kepada tenaga kerja yang dilakukan oleh tenaga profesional kepelatihan dalam satuan waktu yang bertujuan untuk meningkatkan kemampuan kerja peserta dalam bidang bidang pekerjaan tertentu guna meningkatkan efektivitas dan produktivitas dalam suatu organisasi.

Program pelatihan peningkatan kompetensi pendidik PAUD di Kabupaten Bolaang Mongondow Utara telah dilaksanakan sejak tahun 2015 sampai saat ini. Peserta pelatihan adalah pendidik PAUD yang memiliki kualifikasi pendidikan yang berbeda-beda. Idealnya setelah mengikuti pelatihan pendidik memperoleh tiga hal hal, yaitu: (1) bertambahnya pengetahuan, (2) bertambahnya keterampilan, dan (3) perubahan sikap. Namun, sampai saat ini tidak diketahui apakah ketiga hal tersebut telah dimiliki oleh peserta pelatihan atau tidak.

Saat ini yang terjadi di Kabupaten Bolaang Mongondow Utara bahwa keberhasilan suatu program pelatihan khususnya program pelatihan peningkatan kompetensi pendidik PAUD hanya dilihat dari terlaksananya program pelatihan tersebut tanpa memperhatikan apakah program pelatihan tersebut telah sesuai dengan perencanaan awal atau memiliki dampak untuk peserta pelatihan. Evaluasi pelatihan sering hanya ditujukan kepada evaluasi terhadap prestasi peserta setelah mengikuti pelatihan atau kembali ke lembaga PAUD masing-masing dengan mengadakan ujian-ujian baik secara lisan maupun secara tertulis. Dengan kata lain bahwa masih ada anggapan apabila peserta pelatihan banyak yang lulus, maka pelatihan itu dikatakan telah berhasil dengan baik.

Untuk itu penulis merasa bahwa program pelatihan peningkatan kompetensi pendidik PAUD perlu dievaluasi. Evaluasi pelatihan penting dan perlu dilaksanakan, karena: (1) untuk menyelenggarakan suatu pelatihan diperlukan biaya yang cukup besar. Agar biaya yang dikeluarkan tidak sia-sia dan pelatihan yang diselenggarakan itu dapat mencapai sasarannya, (2) dalam evaluasi orang 
berusaha menentukan nilai atau manfaat pelatihan dengan menggunakan informasi yang tersedia.

Evaluasi atau penilaian berarti penentuan nilai. Penilaian pelatihan berarti penentuan nilai atau penentuan manfaat daripada pelatihan. Evaluasi pelatihan menunjukkan suatu usaha untuk memperoleh informasi atau keterangan tentang hasil suatu program pelatihan dan menentukan nilai pelatihan dipandang dari sudut informasi tersebut. Evaluasi program pelatihan merupakan suatu proses untuk mendapatkan informasi tentang hasil pelatihan. Dengan demikian fokus evaluasi pelatihan adalah pada hasil, baik hasil yang berupa proses maupun produk. Informasi hasil pembelajaran ini kemudian dibandingkan dengan hasil pelatihan yang telah ditetapkan. Jika hasil nyata pelatihan sesuai dengan hasil yang ditetapkan, maka pelatihan dapat dikatakan efektif. Sebaliknya, jika hasil nyata pelatihan tidak sesuai dengan hasil pelatihan yang ditetapkan, maka pelatihan dikatakan kurang efektif.

Evaluasi merupakan salah satu komponen yang harus dilakukan oleh suatu lembaga diklat, guna untuk mengetahui keberhasilan program yang telah direncanakan. Hasil yang diperoleh dari kegiatan evaluasi ini dapat dijadikan feedback dalam memperbaiki dan menyempurnakan program diklat selanjutnya. Disisi lain, hasil dari kegiatan evaluasi bukan hanya untuk mengukur tingkat prestasi akademik peserta didik, tetapi juga dapat memberikan informasi secara menyeluruh yang dapat dijadikan informasi yang berguna dalam pengambilan keputusan untuk kepentingan peningkatan kualitas kegiatan pedidikan dan pelatihan.

Evaluasi yang digunakan dalam penelitian ini adalah model CIPP yaitu suatu model evaluasi yang berorientasi pada hasil. Yang dimaksudkan adalah bagaimana hasil yang didapatkan oleh pendidik dengan adanya program pelatihan yang dilaksanakan oleh Dinas Pendidikan dan Kebudayaan Kabupaten Bolaang Mongondow Utara. Hasil yang dicapai tentunya tidak lepas dari aspek-aspek lain yang menyertainya. Ada 3 langkah yang termasuk kedalam evaluasi model stake yaitu aspek masukan, proses dan hasil. Ketiga langkah model evaluasi tersebut 
digunakan untuk mengungkapkan hasil evaluasi pada aspek masukan, proses, dan hasil.

Evaluasi program pelatihan peningkatkan kompetensi pendidik pada aspek masukan difokuskan pada analisis kebutuhan, desain pelatihan, isi program pelatihan, sarana prasarana pelatihan, dan pembiayaan. Aspek proses meliputi kegiatan fasilitator dalam pelatihan, kegiatan peserta dalam pelatihan, metode, peraturan pelatihan, dan penilaian. Pada aspek hasil difokuskan pada kompetensi kepribadian, kompetensi sosial, kompetensi pedagogik, dan kompetensi profesional

Mencermati berbagai permasalahan nyata dikaitkan harapan yang ingin dicapai maka dipandang perlu untuk mengkaji masalah evaluasi program pelatihan peningkatan kompetensi pendidik dalam penelitian yang berjudul: Evaluasi Program Pelatihan Peningkatan Kompetensi Pendidik PAUD di Kabupaten Bolaang Mongondow Utara.

\section{METODE}

Dalam penelitian ini metode yang digunakan adalah metode kualitatif (qualitative research). Bogdan dan Taylor (Moleong, 2007: 4) mendefinisikan metodologi kualitatif sebagai prosedur penelitian yang menghasilkan data deskriptif berupa kata-kata tertulis atau lisan dari orang-orang dan perilaku yang dapat diamati. Pendekatan ini diarahkan pada latar dari individu tersebut secara holistik (utuh). Jadi dalam hal ini tidak boleh mengisolasikan individu atau organisasi ke dalam variabel atau hipotesis, tapi perlu memandangnya sebagai bagian dari suatu keutuhan.

Creswell (2003: 5) mengemukakan bahwa disain penelitian merupakan plan of action that links the philosophical assumptions to specipic methods. Berkaitan dengan pengertian ini yang dikaitkan dengan tujuan penelitian yang ingin di capai, penelitian ini didesain seperti pada diagram berikut: 


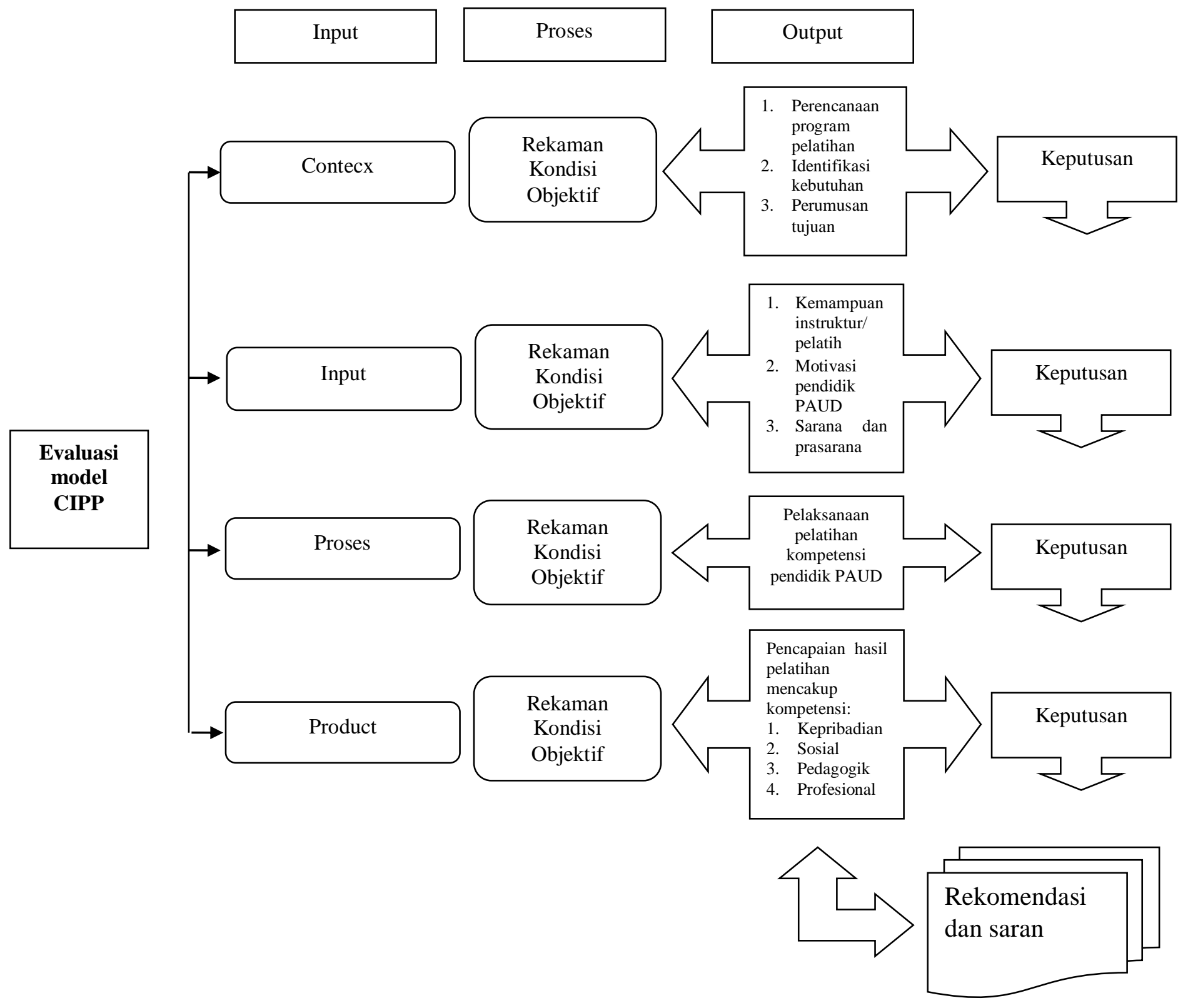

Gambar 1. Desain Penelitian

Untuk mendapatkan kelengkapan informasi yang sesuai dengan fokus penelitian maka yang dijadikan teknik pengumpulan data adalah sebagai berikut :

a. Observasi (pengamatan)

Observasi adalah pengamatan yang dilakukan secara sengaja, sistematis, mengenai fenomena sosial dengan gejala-gejala psikis untuk kemudian dilakukan pencatatan (Subagyo, 1997: 63). Teknik ini dilakukan untuk 
mengetahui proses dan evaluasi program pelatihan peningkatan kompetensi pendidik PAUD di Kabupaten Bolaangmongondow Utara.

b. Wawancara (interview)

Wawancara adalah percakapan dengan maksud tertentu. Percakapan itu dilakukan oleh dua pihak, yaitu pewawancara (interviewer) yang mengajukan pertanyaan dan terwawancara (interviewee) yang memberikan jawaban atas pertanyaan itu (Moleong, 2009: 186). Wawancara dilakukan dalam rangka mengetahui dan mengkaji apa yang menjadi fokus dalam penelitian ini. Pada kegiatan wawancara peneliti menyiapkan garis-garis besar pertanyaan yang kemudian akan berkembang pada saat wawancara terjadi. Teknik ini dilakukan untuk mengetahui masukan, proses dan hasil evaluasi program pelatihan peningkatan kompetensi pendidik PAUD di Kabupaten Bolaang Mongondow Utara.

c. Dokumentasi

Dokumen merupakan catatan peristiwa yang sudah berlalu. Dokumen bisa berbentuk tulisan, gambar, atau karya-karya monumental dari seseorang (Sugiyono, 2009: 329). Dokumen yang ditunjukkan dalam hal ini adalah data pendidik PAUD, dan data yang berhubungan dengan aspek masukan, proses, dan hasil pelatihan di Kabupaten Bolaang Mongondow Utara.

\section{HASIL DAN PEMBAHASAN}

Pembahasan terhadap evaluasi program pelatihan peningkatan kompetensi pendidik PAUD di Kabupaten Bolaang Mongondow Utara menggunakan model evaluasi CIPP (context, input, proses, dan product). Aspek-aspek yang masuk pada komponen komteks meuliputi rancangan keputusan, analisis kebutuhan dan tujuan program pelatihan. Adapun aspek input berkaitan dengan desain pelatihan, isi program, sarana prasarana dan pembiayaan. Aspek-aspek komponen proses meliputi: kegiatan fasilitator, kegiatan peserta, metode, penerapan tata tertib. Aspek-aspek komponen produk meliputi: kompetensi kepribadian, kompetensi sosial, kompetensi pedagogik dan kompetensi profesional. 


\section{Hasil Evaluasi Komponen Konteks Program Pelatihan Peningkatan Kompetensi Pendidik PAUD di Kabupaten Bolaang Mongondow Utara.}

Dalam melaksanakan evaluasi program pelatihan mencakup komponen konteks memerlukan rancangan rancangan keputusan, analisis kebutuhan, dan tujuan program pelatihan. Evaluasi konteks merupakan kondisi eksternal yang harus diinternalkan dalam menyusun program pelatihan peningkatan kompetensi pendidik PAUD di Kabupaten Bolaang Mongondow Utara. Data hasil penelitian dianalisis secara kualitatif, dalam penelitian ini analisis kualitatif menggunakan model analisis Miles \& Huberman (1984), yaitu data reduction (reduksi data), data display (displai data), dan conclusion drawing/verification (verivikasi). Hasil tahapan analisis kualitataif kemudian digunakan untuk menarik kesimpulan.

Tabel 1. Rangkuman hasil penelitian pada evaluasi konteks

\begin{tabular}{|c|c|c|c|}
\hline Indikator & Dimensi & Analisis Kualitatif & Kategori \\
\hline \multirow[t]{3}{*}{ Context (konteks) } & $\begin{array}{ll}\text { a. } & \begin{array}{l}\text { Rancangan } \\
\text { keputusan }\end{array}\end{array}$ & $\begin{array}{l}\text { Tujuan rancangan keputusan: } \\
\text { a. Memberikan pemahaman } \\
\text { aturan kepada pelaksana } \\
\text { program pelatihan } \\
\text { b. Mengurangi resiko terjadinya } \\
\text { komunikasi tidak searah } \\
\text { c. Menentukan hasil capaian } \\
\text { evaluasi pelatihan }\end{array}$ & Baik \\
\hline & $\begin{array}{ll}\text { b. } & \text { Analisis } \\
\text { kebutuhan }\end{array}$ & $\begin{array}{l}\text { a. Identifikasi kebutuhan peserta } \\
\text { b. Tingkat pendidikan yang } \\
\text { relevan }\end{array}$ & Baik \\
\hline & $\begin{array}{ll}\text { c. } & \text { Tujuan } \\
\text { pelatihan }\end{array}$ & $\begin{array}{l}\text { Peningkatan kompetensi pendidik } \\
\text { PAUD }\end{array}$ & Baik \\
\hline
\end{tabular}

Kegiatan analisis kebutuhan pelatihan merupakan suatu proses pengumpulan dan analisis data dalam rangka mengidentifikasi bidang-bidang atau faktor-faktor apa saja yang ada di dalam organisasiyang perlu ditingkatkan atau diperbaiki agar kinerja pegawai dan produktivitas organisasimenjadi meningkat. Tujuan dari kegiatan ini adalah untuk memperoleh data akurat tentang apakah ada kebutuhan untuk menyelenggarakan pelatihan organisasi atau menggunakan trainer dari luar. 


\section{Hasil Evaluasi Komponen Input Program Pelatihan Peningkatan Kompetensi Pendidik PAUD di Kabupaten Bolaang Mongondow Utara}

Hasil evaluasi terhadap komponen masukan Pelatihan kompetensi pendidik PAUD di Kabupaten Bolaang Mongondow Utara seluruhnya berada pada kategori sangat baik, desain pelatihan, isi program, sarana prasarana dan pembiayaan.

Pada aspek masukan desain pelatihan merupakan keseluruhan, struktur, kerangka, atau outline, dan urutan atau sistematika kegiatan pelatihan. Selain itu, desain pelatihan juga dapat diartikan sebagai proses perencanaan yang sistematik yang dilakukan sebelum kegiatan pengembangan atau pelaksanaan sebuah pelatihan.

Langkah pertama yang perlu dilakukan dalam menerapkan desain pelatihan adalah menentukan kemampuan atau kompetensi yang perlu dimiliki oleh peserta pelatihan setelah menempuh program pelatiahan. Hal ini disebut dengan istilah tujuan pelatian atau instructional goal. Rumusan tujuan pelatihan dapat dikembangkan baik dari rumusan tujuan pelatihan yang sudah ada pada proposal maupun yang dihasilkan dari proses analisis kebutuhan (training need assessment).

Dalam merumuskan tujuan pelatihan yang bersifat spesifik, ada beberapa hal yang perlu mendapatkan perhatian, yaitu: (1) menentukan pengetahuan dan keterampilan yang perlu dimiliki oleh peserta pelatihan setelah menempuh proses pelatihan, (2) kondisi yang diperlukan agar peserta pelatihan dapat melakukan unjuk kemampuan dari pengetahuan yang telah dipelajari, (3) indikator atau kriteria yang dapat digunakan untuk menentukan keberhasilan peserta pelatihan dalam menempuh proses pelatihan, (4) menyatakan tujuan (states objectives).

Pada aspek masukan berupa isi program pelatihan. Isi program ditentukan oleh identifikasi kebutuhan-kebutuhan dan sasaran-sasaran pelatihan. Apapun isinya, program pelatihan hendaknya memenuhi kebutuhankebutuhan organisasi dan peserta. Pada peserta juga perlu meninjau isi program, apakah relevan dengan kebutuhan atau motivasinya untuk mengikuti 
pelatihan tersebut rendah atau tinggi. Agar isi program pelatihan efektif, prinsip-prinsip belajar harus diperhatikan.

Sebenarnya persoalan performansi bisa disiatasi melalui perubahan dalam system feedback, seleksi atau imbalan, dan juga melalui pelatihan. Atau akan Iebih mudah dengan melakukan pemecatan terhadap pegawai selama masa percobaannya. Jika pelatihan merupakan Solusi terbaik maka para manajer atau supervisor harus memutuskan program pelatihan yang tepat yang bagaimana yang harus dijalankan.

\section{Hasil Evaluasi Komponen Proses Program Pelatihan Peningkatan Kompetensi Pendidik PAUD di Kabupaten Bolaang Mongondow Utara.}

Pembahasan terhadap evaluasi komponen proses program pelatihan di Kabupaten Bolaang Mongondow Utara difokuskan pada aspek: kegiatan fasilitator, kegiatan peserta, metode dan penerapan peraturan tata tertib.

Hasil penelitian menunjukkan bahwa seluruh komponen proses berada pada kategori sangat baik atau di atas 91.1\%. Hal ini mengindikasikan bahwa proses pelatihan yang meliputi keseluruhan komponen proses berada pada kategori sangat baik.

Fasilitator dalam melaksanakan kegiatan kepelatihan berpedoman pada aturan-aturan pelatihan dimana tahapan-tahapan kegiatan pelatihan meliputi kegiatan pendahuluan, kegiatan inti dan kegiatan penutup. Secara umum tahapan pembelajaran menjadi tiga tahapan sebagai berikut tahapan kegiatan prapembelajaran atau kegiatan awal pembelajaran, kegiatan inti pembelajaran dan kegiatan akhir pembelajaran. Setiap tahapan tersebut ditempuh secara sistematis, efektif dan efisien. Proses pembelajaran merupakan salah satu tahapan penting dalam pembelajaran. Oleh karena itu, proses pembelajaran perlu ditempuh melalui prosedur yang sistematis dan sistemik. Prosedur pembelajaran tersebut merupakan proses yang berurutan dalam membentuk kemampuan peserta pelatihan sesuai dengan tujuan yang telah ditentukan.

Salah satu aspek yang mempengaruhi keberhasilan pembelajaran adalah kemampuan fasilitator dalam mengelola pembelajaran, dalam prosesnya pengelolaan tersebut harus diarahkan hingga menjadi suatu proses bermakna 
dan kondusif dalam pembentukan kemampuan peserta pelatihan. Oleh karena itu, kegiatan belajar selain dikembangkan secara sistematis, efektif dan efisien juga perlu variasi kegiatan sebagai alternatif untuk menumbuhkembangkan motivasi dan aktivitas peserta pelatihan dalam belajar. Seperti dikemukakan di atas bahwa dalam proses pembelajaran ada tiga tahapan prosedur yang perlu ditempuh yaitu ; prapembelajaran atau sering juga disebut sebagai awal pembelajaran, inti pembelajaran dan akhir atau penutup pembelajaran.

Kegiatan pendahuluan dalam pembelajaran sering pula disebut dengan pra-instruksional. Fungsi kegiatan tersebut utamanya adalah untuk menciptakan awal pembelajaran yang efektif yang memungkinkan peserta pelatihan dapat mengikuti proses pembelajaran dengan baik. Efisiensi waktu dalam kegiatan pendahuluan pembelajaran perlu diperhatikan, karena waktu yang tersedia untuk kegiatan tersebut relatif singkat sekitar 5 (lima) menit. Oleh karena itu, dengan waktu yang relatif singkat diharapkan fasilitator dapat menciptakan kondisi awal pembelajaran yang baik, sehingga aktivitas-aktivitas pada awal pembelajaran tersebut dapat mendukung proses dan hasil pembelajaran peserta pelatihan.

Dari uraian di atas, menunjukan bahwa betapa pentingnya prapembelajaran atau kegiatan pendahuluan dalam proses pembelajaran dikondisikan sedemikian rupa. Supaya dapat melaksanakan kegiatan awal pembelajaran seperti yang diharapkan diatas, marilah kita kaji kegiatankegiatan apa saja yang perlu dilaksanakan hingga tercipta proses prapembelajaran yang efektif? Proses pembelajaran sangat dipengaruhi oleh kegiatan awal atau pendahuluan dalam pembelajaran. Oleh sebab itu kegiatan awal dalam pembelajaran harus direncanakan dan dilaksanakan secara sistematis, fleksibel, efektif, dan efisien.

\section{Hasil Evaluasi Komponen Produk Program Pelatihan Peningkatan Kompetensi Pendidik PAUD di Kabupaten Bolaang Mongondow Utara.}

Pembahasan tentang evaluasi komponen produk Program Pelatihan kompetensi pendidik PAUD di Kabupaten Bolaang Mongondow Utara difokuskan kompetensi kepribadian, sosial, pedagogik dan profesional. Hasil 
penelitian menunjukkan bahwa tiga komponen yakni kompetensi kepribadian, kompetensi pedagogik dan kompetensi profesional berada pada kategori cukup sementara kompetensi sosial berada pada kategori baik. Secara umum kompetensi pendidik PAUD setelah melaksanakan pelatihan berada pada kategori cukup atau 69.9\% Hal ini mengindikasikan bahwa pelaksanaan pelatihan masih perlu ditingkatkan untuk meningkatkan keseluruhan kompetensi guru.

Hasil penelitian ini mengindikasikam bahwa pribadi pendidik memiliki andil yang sangat besar terhadap pendidikan, khususnya dalam kegiatan pembelajaran. Pribadi pendidik juga sangat berperan dalam membentuk pribadi peserta didik. Ini dapat dimaklumi karena manusia merupakan makhluk yang suka mencontoh, termasuk mencontoh pribadi gurunya dalam membentuk pribadinya. Semua itu menunjukkan bahwa kompetensi personal atau kepribadian pendidik sangat dibutuhkan oleh peserta didik dalam proses pembentukan pribadinya. Oleh karena itu, wajar ketika orang tua mendaftarkan anaknya kesekolah akan mencari tahu dulu siapa guru-guru yang akan membimbing anaknya.

Kompetensi kepribadian sangat besar pengaruhnya terhadap pertumbuhan dan perkembangan pribadi para peserta didik. Kompetensi kepribadian ini memiliki peran dan fungsi yang sangat penting dalam membentuk kepribadian anak, guna menyiapkan dan mengembangkan sumber daya manusia (SDM), serta mensejahterakan masyarakat, kemajuan Negara, dan bangsa pada umumnya.

Sehubungan dengan uraian tersebut, maka pendidik dituntut untuk memiliki kompetensi kepribadian yang memadai, bahkan kompetensi ini akan melandasi atau menjadi landasan bagi kompetensi-kompetensi lainnya. Dalam hal ini, pendidik tidak hanya dituntut untuk mampu memaknai pembelajaran, tetapi dan yang paling penting adalah bagaimana pendidik menjadikan pembelajaran sebagai ajang pembentukan kompetensi dan perbaikan kualitas pribadi peserta didik 
Guru diharapkan dapat menjadi teladan bagi peserta didik baik dalam pergaulan disekolah maupun dimasyarakat. Namun, ada juga sikap pendidik yang kurang disukai seperti : pendidik yang sombong (tidak suka menegur atau ditegur saat bertemu diluar sekolah ), pendidik yang suka merokok, memakai baju tidak rapi, sering datang kesiangan, dll. Oleh krena itu, pendidik haruslah berusaha untuk tampil menyenangkan peserta didik, agar dapat mendorong mereka untuk belajar. pendidik harus berani tampil beda, karena dituntut untuk memberikan dan memelihara pandangan tentang keagungan kepada peserta didiknya. Mengemban fungsi ini pendidik harus terampil dalam berkomunikasi dengan peserta didik di segala umur

\section{SIMPULAN}

Berdasarkan hasil dan pembahasan maka sejumlah kesimpulan dapat diutarakan berikut ini.

1. Evaluasi komponen konteks program pelatihan peningkatan kompetensi pendidik PAUD di Kabupaten Bolaang Mongondow Utara berada pada baik, meliputi: rancangan keputusan, analisis kebutuhan pelatihan, dan tujuan program pelatihan kompetensi.

2. Hasil evaluasi komponen masukan program pelatihan peningkatan kompetensi pendidik PAUD di Kabupaten Bolaang Mongondow Utara berada pada kategori sangat baik, meliputi: desain pelatihan, isi program, sarana prasarana dan pembiayaan.

3. Hasil evaluasi komponen proses program pelatihan peningkatan kompetensi pendidik PAUD di Kabupaten Bolaang Mongondow Utara berada pada kategori sangat baik meliputi kegiatan fasilitator, kegiatan peserta, metode, penerapan peraturan tata tertib dan penilaian.

4. Hasil evaluasi komponen hasil program pelatihan peningkatan kompetensi pendidik PAUD di Kabupaten Bolaang Mongondow Utara berada pada kategori cukup, meliputi: kompetensi kepribadian, kompetensi sosial, kompetensi pedagogik dan kompetensi profesional. 


\section{DAFTARPUSTAKA}

Arikunto Suharsimi, 2004. Evaluasi Program Pendidikan Pedoman Praktis bagi Praktisi Pendidikan. Jakarta: Bumi Aksara

Arikunto, Suharsimi dan Cepi Syarifudin. 2008. Evaluasi Program Pendidikan. Pedoman Teoretis Praktis Bagi Mahasiswa dan Praktisi Pendidikan. Edisi Kedua. Jakarta : Bumi Aksara

Departemen Pendidikan Nasional. 2007. Prinsip-Prinsip Manajemen Pelatihan. Edisi Kedua. Pusdiklat Pegawai Depdiknas.

Thoha Chabib. 2001. Evaluasi Pendidikan Jakarta: Rajawali Press.

Daryanto, H. 2010. Evaluasi Pendidikan. Jakarta. Rineka Cipta.

Farida Yusuf Toyib. 2008. Evaluasi Program dan Instrumen Evaluasi. Jakarta: PT Rineka Cipta

Hasan, Hamid 2008. Evaluasi Program . Bandung : Remaja Rosdakarya

Hermana. 2008. Evaluasi Program Tingkat Satuan Pendidikan, Alberty: Bandung

Jinan Bandar Lampung. Lampung; Fakultas Keguruan dan Ilmu Pendidikan

Sukmadinata, Nana Syaodih. 2001. Pengembangan Kurikulum Teori dan Praktek. Bandung : PT Remaja Rosdakarya

Sukardi HM. 2008. Evaluasi Pendidikan Prinsip dan Operasionalnya. Jakarta. Bumi Aksara.

Stufflebeam, Daniel L. 2002. CIPP Evaluation Model Checklist: A tool for applying the Fifth Installment of the CIPP Model to assess long-term enterprises. Tersedia pada http://www. ed.uiuc.educir cepublicationsc CIPP.Diakses pada tanggan 14 Juni 2015

Stufflebeam Daniel.L. 2003. Evaluation Theory, Models, and Applications, San Fransisko,Publihed by Josey. Bass

Wibawa Samudra, 2004. Evaluasi Kebijakan Publik. Jakarta; Raja Grafindo Persada

Widoyoko, S.E.P. 2007. Pengembangan Model Evaluasi Pembelajaran IPS SMP. Yogyakarta: PPS UNY. 